\title{
IMPROVEMENT OF METHODS OF THE PROPERTY VALUATION BASED ON MATHEMATICAL AND NUMERICAL MODELING
}

\author{
Olena Slavinska \\ Department of Transport Construction and Property Management \\ National Transport University \\ 1 Omelyanovicha-Pavlenko str., Kyiv, Ukraine, 01010 \\ elenaslavin9@gmail.com \\ Vyacheslav Savenko \\ Department of Transport Construction and Property Management \\ National Transport University \\ 1 Omelyanovicha-Pavlenko str., Kyiv, Ukraine, 01010 \\ svi1310@ukr.net \\ Lyudmila Bondarenko \\ Department of Transport Construction and Property Management \\ National Transport University \\ 1 Omelyanovicha-Pavlenko str., Kyiv, Ukraine, 01010 \\ luda_bond@ukr.net \\ Andrey Bubela \\ Department of Transport Construction and Property Management \\ National Transport University \\ 1 Omelyanovicha-Pavlenko str., Kyiv, Ukraine, 01010 \\ bubelaandrey@ukr.net
}

\begin{abstract}
The conducted researches aimed to analyze modern models and methods of implementation of the comparative approach in property and real estate appraisal, to investigate and evaluate their effectiveness, to suggest ways of further improving the methods of property valuation.

To achieve this aim, the authors carried out a series of computational experiments on a computer. The essence of these experiments was the comparative evaluation of the cost of test properties based on the following methods: expert evaluation, solving systems of linear algebraic equations, based on the normalized distances in the space of pricing factors and the correlation-regression method. An analysis was made of the influence of methods of digitizing the initial data (pricing factors) on the final cost of real estate.

On the basis of the studies, prospective ways and directions for further improvement of the methods of property valuation are determined.

Keywords: real estate, valuation of property and real estate, digitization of source data, property valuation method, comparative approach in real estate appraisal, real estate value.

\section{Introduction}

In conditions of active reformation of property relations, the need for services for valuation of property and property rights is regularly growing. The problems of property valuation related to property alienation, property disputes, the problem of land reform, the formation of an alternative model of partnership between the public and private sectors, require objective decisions of the appraisal expertise [1-6]. Accordingly, there is a need to improve the toolkit of the procedure for conducting property valuation by applying modern mathematical models and methods to obtain an objective market value of property and to make effective management decisions.
\end{abstract}




\section{Literature review and problem statement}

To date, property valuation in Ukraine [7], as in the countries of Europe [5], Australia [6] is conducted according to 3 main approaches: comparative, profitable and costly, each of which has advantages and disadvantages (Table 1).

Table 1

Comparative analysis of different approaches to property valuation

\begin{tabular}{|c|c|c|}
\hline Approach & Advantages & Disadvantages \\
\hline profitable & $\begin{array}{l}\text { - the cost of the valuation depends on the } \\
\text { profit that the valuated object can generate } \\
\text { - takes into account the market aspect } \\
\text { through the discount rate; } \\
\text { - takes into account the economic aging; } \\
\text { - is universal. }\end{array}$ & $\begin{array}{l}\text { - cumbersome calculations; } \\
\text { - the results are of a probabilistic nature; } \\
\text { - the difficulty of obtaining information for making } \\
\text { calculations; } \\
\text { - high degree of risk; } \\
\text { - valuation subjectivity. }\end{array}$ \\
\hline comparative & $\begin{array}{l}\text { - a completely market-based method; } \\
\text { - in the total cost reflects the opinion of } \\
\text { typical sellers and buyers; } \\
\text { - allows to take into account the uniqueness } \\
\text { of each object; } \\
\text { - simplicity of interpretation of results. }\end{array}$ & $\begin{array}{l}\text { - does not take into account future expectations; } \\
\text { - dependence on market stability; } \\
\text { - the complexity of reconciling sales data is significantly } \\
\text { different; } \\
\text { - cumbersome calculations; } \\
\text { - the possibility of the absence of analogical objects; } \\
\text { - difficulties in gathering the necessary initial } \\
\text { information. }\end{array}$ \\
\hline costly & $\begin{array}{l}\text { - is based on real assets; } \\
\text { - the only possible for some types of } \\
\text { enterprises; } \\
\text { - allows to display the actual costs incurred } \\
\text { by the enterprise [5]. }\end{array}$ & $\begin{array}{l}\text { - does not take into account future expectations; } \\
\text { - does not take into account some intangible assets; } \\
\text { - does not take into account the effectiveness of the use } \\
\text { of assets; } \\
\text { - the book value of the property never corresponds to its } \\
\text { market value. }\end{array}$ \\
\hline
\end{tabular}

To date, for the valuation of property and real estate, the most common is the comparative approach, which involves determining the value of the valuated object by comparing the prices of recent sales of similar properties. The approach is based on taking into account the principles of supply and demand in the real estate market.

This approach is implemented in 4 stages [7]:

1. Study of the state, development trends and features of the real estate market segment to which the valuated object belongs.

2. Collection and verification of information about analogical objects, analysis of collected information.

3. Choosing a method for implementing a comparative approach.

4. Reconciliation of adjusted prices of analogical objects and determination of the value of the market value of the property being valued.

One of the most difficult stages in implementing a comparative approach in valuation of property and real estate is the stage of choosing the method of its implementation (stage 3), which requires the definition of certain scientifically grounded criteria for choosing a particular method.

Therefore, it is important to analyze modern methods of implementing a comparative approach in valuation of property and real estate, assess the effectiveness of existing methods and models, and offer the most effective tools for performing valuation activities.

\section{The aim and objectives of research}

The conducted researches aimed to analyze modern models and methods of implementation of the comparative approach in property and real estate appraisal, to investigate and evaluate their effectiveness, to suggest ways of further improving the methods of property valuation. 
To achieve this aim, the following tasks are solved in the work:

- to conduct an analysis of methodological approaches to the valuation of property and real estate;

- to analyze the methods of implementing a comparative approach in the valuation of property and real estate;

- to conduct a comparative analysis of the calculation of the property value on the basis of expert valuation methods, solving the system of linear equations, the method of calculating corrective corrections based on the normalized distances in the space of pricing factors and on the basis of the correlation-regression method;

- to carry out computational experiments to investigate the effect of the process of digitizing the original data on the final value of the real estate object when implementing the studied methods.

\section{The essence and methods of research of modern methods of implementing a comparative} approach in valuation of property and real estate

\section{1. Object, subject and methods of research}

The objects of this research are real estate objects.

The subject of this research is methods for determination of the value of real estate objects in the framework of a comparative approach.

Research methods are mathematical and numerical modeling.

The research is carried out in two main directions:

1. Computational experiment on the study of existing methods for implementing a comparative approach in the valuation of property and real estate, the essence of which was the comparative valuation of test real estate objects obtained by different methods.

2. Computational experiment to study the sensitivity of the methods under consideration to implement a comparative approach in the valuation of property and real estate according to the procedure for digitizing the initial data (pricing factors).

\section{2. Investigated methods for implementing a comparative approach in valuation of property and real estate}

Expert method of determining corrective corrections

The simplest and most popular method for implementing a comparative approach in real estate valuation is the expert method of determining corrective amendments. It is based on making corrections to the cost of analogical objects for certain pricing factors, by comparing them with the valuation object. Most often, amendments are introduced to: terms of sale, location, technical condition and others. At the same time, a certain step is chosen, based on the vision of a specific expert. Most often this step is $5 \%$. The final value of the valuation object is derived as the arithmetic mean, modal or median value $[2-4,6]$.

It is clear that this method is very dependent on the qualification of the expert and the choice of the calculated step.

The method of calculating corrective corrections based on the solution of a system of linear algebraic equations (SLAE)

The method of calculating corrective corrections based on the solution of a system of linear algebraic equations (SLAE) is more substantiated and formalized [6-8]. According to this method, the value of the property is based on the formula:

$$
\mathrm{V}_{0}=\mathrm{P}_{\mathrm{i}}+\sum_{\mathrm{i}=1}^{\mathrm{m}} \Delta \mathrm{P}_{\mathrm{ij}},
$$

where $\mathrm{V}_{0}$ - the value of the valuation object, $\mathrm{P}_{\mathrm{i}}$ - the price of the $\mathrm{i}$-th counterpart; $\Delta \mathrm{P}_{\mathrm{ij}}$ - adjustment of the price of the $\mathrm{i}$-th analogue to the difference in the object of estimation by the $\mathrm{j}$-th pricing factor.

According to the model (1), it is necessary to compare the object in succession with each of the selected analogs. As a result, let's obtain a system of linear equations: 


$$
\left\{\begin{array}{l}
\mathrm{V}_{0}-\Delta \mathrm{x}_{11} \Delta \mathrm{P}_{1}-\Delta \mathrm{x}_{12} \Delta \mathrm{P}_{2}-\ldots-\Delta \mathrm{x}_{1 \mathrm{~m}} \Delta \mathrm{P}_{\mathrm{m}}=\mathrm{P}_{1} \\
\mathrm{~V}_{0}-\Delta \mathrm{x}_{21} \Delta \mathrm{P}_{1}-\Delta \mathrm{x}_{22} \Delta \mathrm{P}_{2}-\ldots-\Delta \mathrm{x}_{2 \mathrm{~m}} \Delta \mathrm{P}_{\mathrm{m}}=\mathrm{P}_{2} \\
\cdots \\
\mathrm{V}_{0}-\Delta \mathrm{x}_{\mathrm{n} 1} \Delta \mathrm{P}_{1}-\Delta \mathrm{x}_{\mathrm{n} 2} \Delta \mathrm{P}_{2}-\ldots \Delta \mathrm{x}_{\mathrm{nm}} \Delta \mathrm{P}_{\mathrm{m}}=\mathrm{P}_{\mathrm{n}}
\end{array}\right.
$$

It is more convenient to find the solution of this system by the matrix method.

The main drawback of this method is that the number of analogs should exceed by 1 number of factors. This certainly causes certain difficulties in the implementation of this method, related to the need to search for additional analogues or a reduction in the number of pricing factors.

The method of calculating corrective corrections based on the normalized distances in the space of pricing factors

Another formalized method has no limitations on the number of pricing factors and analogical objects is the method of calculating corrective corrections based on the normalized distances in the space of pricing factors [8]. According to it, the definition of the value of the property is carried out in 4 stages.

Preparatory stage. At this stage, the state matrix $\mathrm{M}$ is formed:

$$
\mathrm{M}=\left(\begin{array}{ccc}
\mathrm{x}_{01} \mathrm{x}_{02} & \cdots & \mathrm{x}_{0 \mathrm{~m}} \\
\vdots & \ddots & \vdots \\
\mathrm{x}_{\mathrm{n} 1} \mathrm{x}_{\mathrm{n} 2} & \cdots & \mathrm{x}_{\mathrm{nm}}
\end{array}\right),
$$

where $\mathrm{n}$ is the number of analogical objects; $\mathrm{x}_{01}, \mathrm{x}_{02}, \ldots, \mathrm{x}_{0 \mathrm{~m}}-$ the object of valuation; $\mathrm{x}_{\mathrm{n} 1}, \mathrm{x}_{\mathrm{n} 2}, \ldots, \mathrm{x}_{\mathrm{nm}}-\mathrm{i}$-th analogue.

The first stage is the formation of a matrix of congruences

At this stage, let's form the matrix of comparisons $\Delta \mathrm{M}$ by subtracting the value of the first row of the matrix from the corresponding elements of all subsequent rows:

$$
\Delta \mathrm{M}=\left(\begin{array}{ccc}
\Delta \mathrm{x}_{11} \Delta \mathrm{x}_{12} & \cdots & \Delta \mathrm{x}_{1 \mathrm{~m}} \\
\vdots & \ddots & \vdots \\
\Delta \mathrm{x}_{\mathrm{n} 1} \Delta \mathrm{x}_{\mathrm{n} 2} & \cdots & \Delta \mathrm{x}_{\mathrm{nm}}
\end{array}\right) .
$$

Thus, each element of the comparison matrix $\Delta \mathrm{x}_{\mathrm{ij}}$ characterizes the difference between the $\mathrm{i}$-th analogue object and the object of estimation by the $\mathrm{j}$-th factor.

The second stage is the normalization of the matrix of congruences

In order to move away from the different units of measurement of the columns of the matrix $\Delta \mathrm{M}$, each element of the matrix is normalized as follows:

$$
\Delta \mathrm{k}_{\mathrm{ij}}=\frac{\Delta \mathrm{x}_{\mathrm{ij}}}{\sqrt{\sum_{\mathrm{i}=1}^{\mathrm{n}}\left(\Delta \mathrm{x}_{\mathrm{ij}}\right)^{2}}} .
$$

Thus, let's obtain a normalized comparison matrix $+\Delta \mathrm{M}$.

The third stage is the determination of weight coefficients

On the basis of the matrix $+\Delta \mathrm{M}$ let's calculate the distance $\mathrm{l}_{\mathrm{i}}$ from the formula:

$$
\mathrm{l}_{\mathrm{i}}=\sqrt{\sum_{\mathrm{j}=1}^{\mathrm{m}}\left(\Delta \mathrm{k}_{\mathrm{ij}}\right)^{2}}, \mathrm{i}=\overline{1, \mathrm{n} .}
$$

In an n-dimensional Euclidean space, the object of estimation acts as the center of coordinates, and to each analogue object there corresponds a separate point, remote from the center of coordinates (the object of valuation) by the distance $1_{i}$. 

To each quantity $1_{\mathrm{j}}$. it is possible to compare the reciprocal quantity $\mathrm{P}_{\mathrm{i}}=\frac{1}{1_{\mathrm{i}}}$, which can be
transformed into a weighting coefficient by the formula:

$$
\mathrm{v}_{\mathrm{i}}=\frac{\mathrm{p}_{\mathrm{i}}}{\sum \mathrm{p}_{\mathrm{i}}}
$$

The fourth stage is the determination of the value of the valuation object. Taking into account the found weight coefficients, the value of the valuation object is determined by the formula:

$$
\mathrm{C}=\sum_{\mathrm{i}=1}^{\mathrm{n}} \mathrm{v}_{\mathrm{i}} \cdot \mathrm{C}_{\mathrm{i}}
$$

where $\mathrm{C}_{\mathrm{i}}$ - the cost of the $\mathrm{i}$-th analogue object.

This method is guaranteed to give the result of the value of the valuation object, does not exceed the limits of the cost of used analogs.

The advantage of this method is that it takes into account the degree of proximity of the valuation object to the analogue objects.

Correlation-regression method for determining the value of real estate objects

If there is a significant amount of information on analogous objects, then it is reasonable to determine the market value of a real estate object within the framework of a multifactor regression analysis that allows one to assess the degree of influence on the investigated performance indicator of each of the factors introduced into the model with a fixed position at the middle level of other factors [9-18].

Mathematically, the task is reduced to finding an analytical expression, it would better reflect the connection of the factor characteristics with the resultant:

$$
\mathrm{Y}=\mathrm{f}\left(\mathrm{X}_{1}, \mathrm{X}_{2}, \ldots, \mathrm{X}_{\mathrm{n}}\right)
$$

The most difficult problem is choosing the form of communication. However, taking into account that any function of many variables can be reduced to a linear form by logarithmation or substitution of variables, the multiple regression equation can be expressed in a linear form:

$$
Y=a_{0}+a_{1} X_{1}+a_{2} X_{2}+\ldots+a_{n} X_{n}
$$

where $\mathrm{Y}$ - the calculated values of the effective indicator; $X_{1}, X_{2}, \ldots, X_{n}$ - the factors; $a_{0}, a_{1}$, $a_{2}, \ldots a_{n}-$ the equation parameters.

The equation parameters are calculated by the least squares method. So, in the case of two-factor regression:

$$
\begin{aligned}
& \sum \mathrm{Y}=\mathrm{na}_{0}+\mathrm{a}_{1} \sum \mathrm{X}_{1}+\mathrm{a}_{2} \sum \mathrm{X}_{2} \\
& \sum \mathrm{YX}_{1}=\mathrm{a}_{0} \sum \mathrm{X}_{1}+\mathrm{a}_{1} \sum \mathrm{X}_{1}{ }^{2}+\mathrm{a}_{2} \sum \mathrm{X}_{1} \mathrm{X}_{2} \\
& \sum \mathrm{YX}_{2}=\mathrm{a}_{0} \sum \mathrm{X}_{2}+\mathrm{a}_{1} \sum \mathrm{X}_{1} \mathrm{X}_{2}+\mathrm{a}_{2} \sum \mathrm{X}_{2}{ }^{2}
\end{aligned}
$$

Each coefficient of the equation indicates the degree of influence of the relevant factor on the score for a fixed position of other factors.

In order to identify the relative strength of the influence of individual factors and their reserves, it is advisable to calculate the partial elasticity coefficients and beta coefficients by the formulas:

$$
\varepsilon_{3}=a_{i} \frac{\overline{X_{i}}}{\bar{Y}} ; \beta_{3}=a_{i} \frac{\sigma_{X_{3}}}{\sigma_{Y}},
$$


where $a_{i}$ - coefficients of regression at the $i$-th factor; $\bar{X}_{i}-$ the average value of the $i$-th factor; $\bar{Y}-$ the average value of the effective indicator; $\sigma_{X_{3}}-$ the standard deviation of the $i$-th factor; $\sigma_{Y}-$ the standard deviation of the result.

Partial coefficients of elasticity show how many percent the result on the average will change with $1 \%$ change of each factor for a fixed position of other factors.

\section{Analysis of the results of a computational experiment on the methods of realizing the com- parative approach in real estate valuation}

In order to valuate and compare various methods of calculating the value of real estate in the comparative approach, a number of test cases are examined, a fragment of one of which is given below.

Let's suppose that it is necessary to evaluate the property (living quarters), which is characterized by the indicators shown in Table 2. For comparison, 5 analogical objects are selected, the characteristics of which are also given in Table 2. Let's assess the value of the object for such pricing factors: technical condition, location, availability of improvement, the presence of a parking slot.

Table 2

Output data on the subject of valuation and analogical objects

\begin{tabular}{|c|c|c|c|c|c|}
\hline No. & technical condition & Location & Accomplishment & Parking slot & $\begin{array}{l}\text { The cost of } \\
1 \text { sq.m, UAH }\end{array}$ \\
\hline Valuation object & good & Central & water supply lighting & yes & \\
\hline Analogue 1 & good & Central & all the benefits & yes & 13500 \\
\hline Analogue 2 & excellent & middle & all the benefits & yes & 13500 \\
\hline Analogue 3 & satisfactory & middle & water supply lighting & no & 12900 \\
\hline Analogue 4 & satisfactory & middle & lighting & yes & 12850 \\
\hline Analogue 5 & satisfactory & Central & without accomplishment & yes & 12900 \\
\hline
\end{tabular}

According to the expert method of calculating the cost of the valuated object, a standard step of $5 \%$ was chosen. As a result of the calculations, the following results are obtained (Table 3).

Table 3

Result of calculation of cost of valuated object by a method of an expert estimation

\begin{tabular}{cccccc}
\hline No. & \multicolumn{2}{c}{ Corrective amendments, $\%$} & Amount of amendments, \% & Adjusted cost of 1 sq. m, UAH \\
\hline Analogue 1 & 0 & -5 & 0 & -5 & 12825 \\
Analogue 2 & 5 & -5 & 0 & -5 & 12825 \\
Analogue 3 & 5 & 0 & 5 & 15 & 14835 \\
Analogue 4 & 5 & 5 & 0 & 15 & 14777,5 \\
Analogue 5 & 0 & 10 & 0 & 15 & 14835 \\
Object & & average & & & 14019,5 \\
& & median &
\end{tabular}

Further, the cost of the same property is calculated using the SLAU solution method. For this purpose, the initial data were digitized (Table 4).

As a result of the implementation of this method, a solution is obtained in this form (Table 5).

Element $\mathrm{V}_{0}-$ this is the market value of 1 square. $\mathrm{m}$ (for the estimated property 13362.5 UAH.).

Other elements of the obtained matrix $\mathrm{V}$ can be interpreted as follows:

$\Delta \mathrm{P}_{1}=187,5 \mathrm{UAH}-$ correction to the cost of 1 square. $\mathrm{m}$ of the property while improving its technical condition by one point; 
$\Delta \mathrm{P}_{2}=187,5 \mathrm{UAH}$ - correction to the cost of 1 square. $\mathrm{m}$ of the property with a hypothetical improvement in its location by one point;

$\Delta \mathrm{P}_{3}=137.5 \mathrm{UAH}$ - correction to the cost of 1 square. $\mathrm{m}$ of the property while improving the improvement;

$\Delta \mathrm{P}_{4}=87.5 \mathrm{UAH}-$ correction to the cost of 1 square. $\mathrm{m}$ of the property when there is a parking lot.

In order to reveal the dependence of the choice of the method of digitizing the initial data on the final cost of the valuation object, a computational experiment is carried out, a fragment of the results of which are given in Table 6. In the course of the experiment it turned out that the method of digitizing data in this method affects the final result of the cost. In this case, even corrections may occur with a negative sign, contrary to the physical meaning of the problem.

Table 4

Initial data for calculating the value of an object by the SLAU solution method

\begin{tabular}{|c|c|c|c|c|}
\hline pricing factor & Technical condition (TC) & Location (L) & Accomplishment (A) & Park slot (PS) \\
\hline \multicolumn{5}{|c|}{ Ranking } \\
\hline 0 & & & & Yes \\
\hline 1 & Satisfactory & outskirts & without accomplishment & No \\
\hline 2 & Good & middle & lighting & \\
\hline 3 & Excellent & Central & water supply lighting & \\
\hline 4 & & & all the benefits & \\
\hline \multicolumn{5}{|c|}{ Output factors (pricing factors) } \\
\hline Valuation object & 2 & 3 & 2 & 1 \\
\hline Analogue 1 & 2 & 3 & 3 & 1 \\
\hline Analogue 2 & 3 & 2 & 3 & 1 \\
\hline Analogue 3 & 1 & 2 & 2 & 0 \\
\hline Analogue 4 & 1 & 2 & 2 & 1 \\
\hline Analogue 5 & 1 & 3 & 0 & 1 \\
\hline
\end{tabular}

Table 5

The result of calculating the value of the property by the method of SLAU solution

\begin{tabular}{ccccccccccc}
\hline & \multicolumn{3}{c}{ State matrix } & \multicolumn{4}{c}{ Inverse matrix } & \multicolumn{2}{c}{ Vector of values, UAH } \\
\hline 1 & 0 & 0 & 1 & 0 & 0,5 & 0,25 & 0 & $-0,25$ & 0,5 & 13362,5 \\
1 & 1 & -1 & 1 & 0 & $-0,5$ & 0,75 & 0 & $-0,75$ & 0,5 & 187,5 \\
1 & -1 & -1 & 0 & -1 & 0,5 & $-0,25$ & 0 & $-0,75$ & 0,5 & 187,5 \\
1 & -1 & -1 & -1 & 0 & 0,5 & $-0,25$ & 0 & 0,25 & $-0,5$ & 137,5 \\
1 & -1 & 0 & -2 & 0 & 0,5 & $-0,25$ & -1 & 1,25 & $-0,5$ & 87,5
\end{tabular}

Further, the cost of this real estate object is calculated by determining the weight coefficients based on the normalized distances in the space of the pricing factors. For this purpose, data are digitized similar to the previous method and calculations are performed. The obtained results can be interpreted as the value of the object of valuation and the degree of remoteness of the object from the analogical objects (Table 7).

To determine the dependence of the choice of the method of digitizing data on the final cost of the valuation object, a computational experiment is conducted to study this method, a fragment of the results of which are given in Table 8. In the course of the experiment it turned out that the method of digitizing data in this method also affects the final result of the value of the valuation object (Table 8). 
Table 6

Fragment of the results of the computational experiment on the investigation of the method of SLAU solution in valuation of the real estate object

\section{Output data}

Object

TC

\section{Pricing factors}

L
A

PS
Cost, UAH

\section{Experiment 1}

\begin{tabular}{cllllll}
\hline Valuation object & 2 & 3 & 2 & 1 & & 13362,5 \\
A1 & 2 & 3 & 3 & 1 & 13500 & 187,5 \\
A2 & 3 & 2 & 3 & 1 & 13500 & 187,5 \\
A3 & 1 & 2 & 2 & 0 & 12900 & 137,5 \\
A4 & 1 & 2 & 1 & 1 & 12850 & 87,5 \\
A5 & 1 & 3 & 0 & 1 & 12900 & \\
\hline
\end{tabular}

\begin{tabular}{|c|c|c|c|c|c|c|}
\hline \multicolumn{7}{|c|}{ Experiment 2} \\
\hline Valuation object & 3 & 3 & 2 & 1 & & \\
\hline $\mathrm{A} 1$ & 3 & 3 & 3 & 1 & 13500 & 13268,8 \\
\hline A 2 & 5 & 2 & 3 & 1 & 13500 & 93,75 \\
\hline A3 & 1 & 2 & 2 & 0 & 12900 & 187,5 \\
\hline A4 & 1 & 2 & 1 & 1 & 12850 & 137,5 \\
\hline A5 & 1 & 3 & 0 & 1 & 12900 & 87,5 \\
\hline
\end{tabular}

\begin{tabular}{|c|c|c|c|c|c|c|}
\hline \multicolumn{7}{|c|}{ Experiment 3} \\
\hline Valuation object & 2 & 5 & 3 & 1 & & \\
\hline A1 & 2 & 5 & 5 & 1 & 13500 & 12900 \\
\hline A2 & 3 & 3 & 7 & 1 & 13500 & $-87,5$ \\
\hline A3 & 1 & 3 & 3 & 0 & 12900 & 93,75 \\
\hline A4 & 1 & 3 & 1 & 1 & 12850 & 137,5 \\
\hline A5 & 1 & 5 & 0 & 1 & 12900 & 225 \\
\hline
\end{tabular}

Table 7

Calculation of the value of the property by determining the weighting coefficients on the basis of the normalized distances in the space of the pricing factors

\begin{tabular}{cccccc}
\hline Object & $\sum_{\mathrm{j}=1}^{4}\left(\Delta \mathrm{k}_{\mathrm{ij}}\right)^{2}, \mathrm{i}=\overline{1, \mathrm{n}}$ & $\mathrm{l}_{\mathrm{i}}=\sqrt{\sum_{\mathrm{j}=1}^{4}\left(\Delta \mathrm{k}_{\mathrm{ij}}\right)^{2}}, \mathrm{i}=\overline{1, \mathrm{n}}$ & $\mathrm{p}_{\mathrm{i}}=\frac{1}{\mathrm{i}_{\mathrm{i}}}$ & $\mathrm{v}_{\mathrm{i}}=\frac{\mathrm{p}_{\mathrm{i}}}{\sum_{\mathrm{p}_{\mathrm{i}}}}$ & Cost, UAH \\
\hline A1 & 1,14 & 1,07 & 0,94 & 0,15 & 2049,768 \\
A2 & 1,41 & 1,19 & 0,84 & 0,14 & 1846,032 \\
A3 & 0,36 & 0,60 & 1,68 & 0,27 & 3506,582 \\
A4 & 0,50 & 0,71 & 1,42 & 0,23 & 2955,381 \\
A5 & 0,60 & 0,77 & 1,29 & 0,21 & 2703,884 \\
Sum & & 6,17 & 1,00 & 13061,65
\end{tabular}


Table 8

Fragment of the results of the computational experiment on the study of the method of determining the weight coefficients on the basis of the normalized distances in the space of the pricing factors

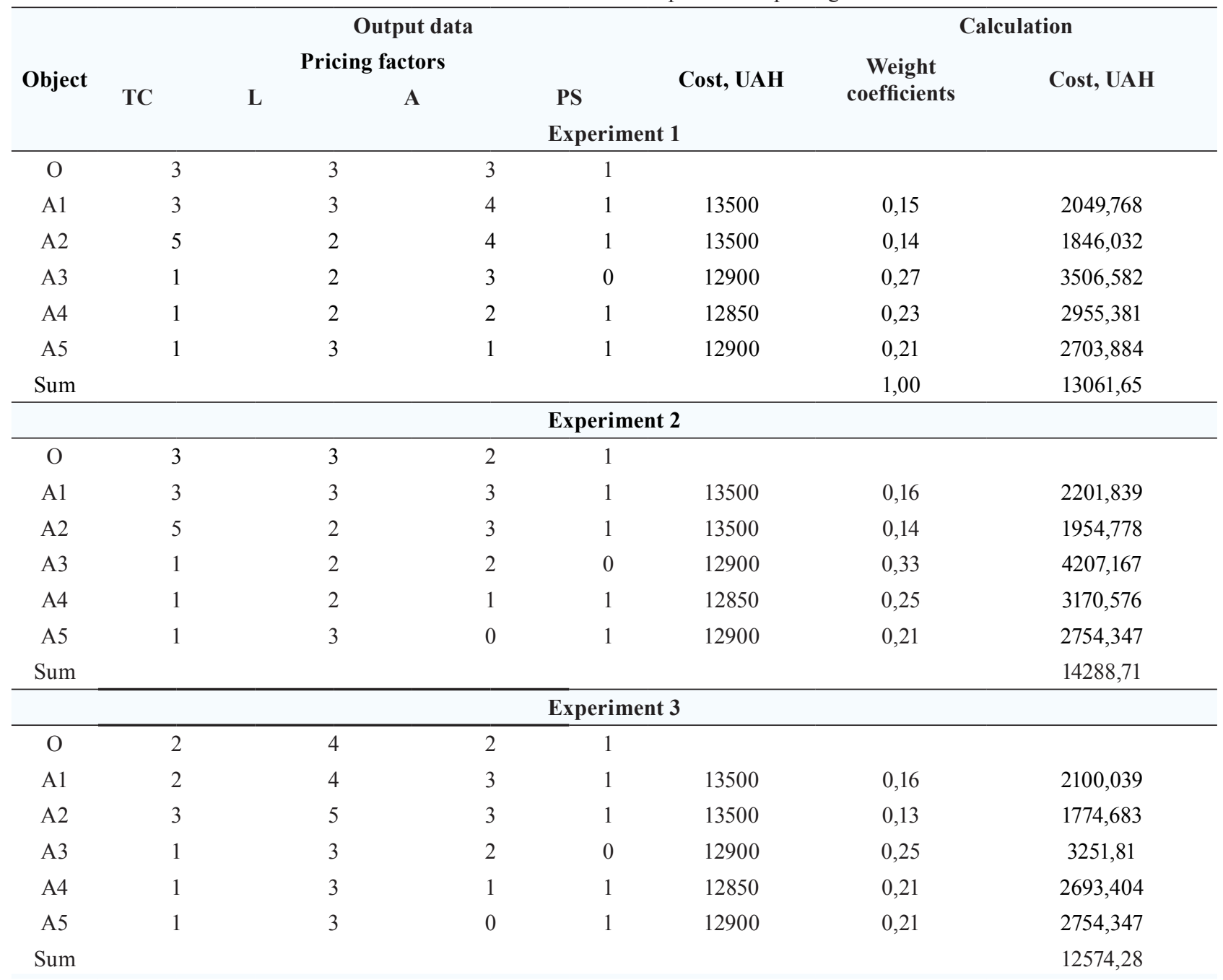

Next, the cost of the property is calculated using the correlation-regression method (Table 9).

Table 9

Calculation of the value of the real estate object by the correlation-regression method

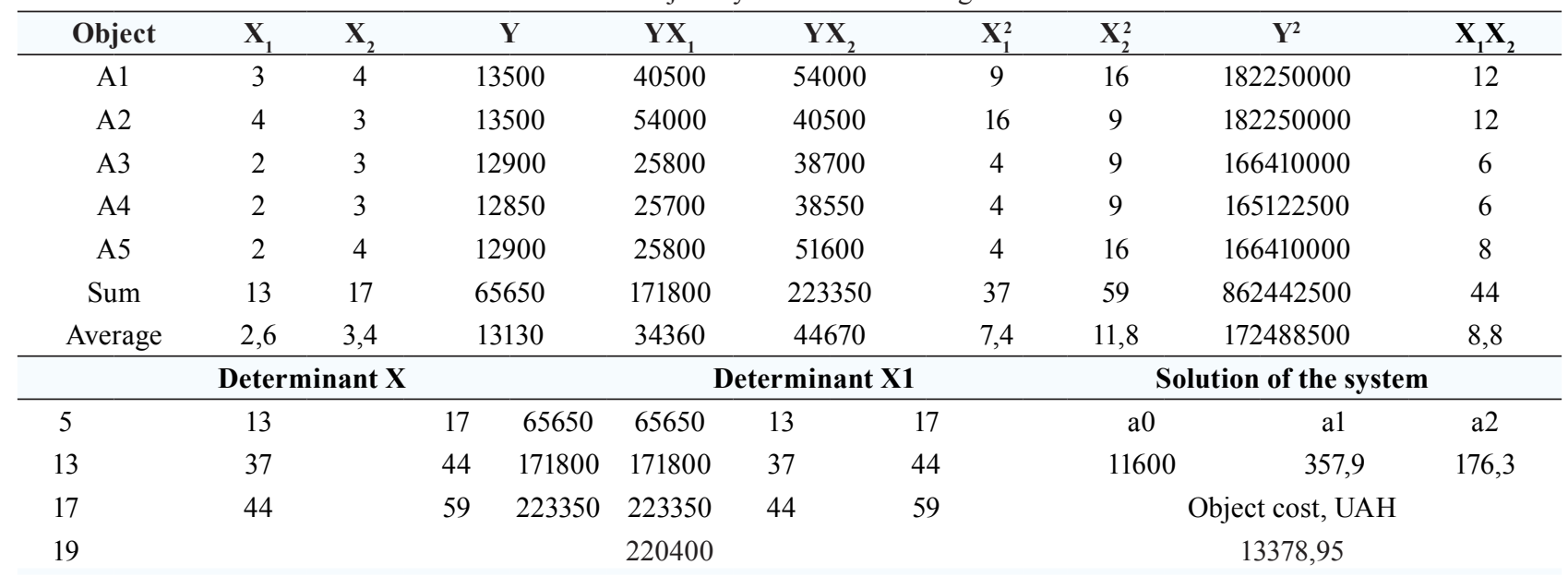


A computational experiment to investigate the correlation-regression method shows that the choice of the method of digitizing the initial data practically does not affect the final result of the cost, which is by far the most significant advantage of this method (Table 10).

Table 10

Fragment of the results of a computational experiment on the investigation of the correlation-regression method of property valuation

\begin{tabular}{|c|c|c|c|c|c|c|c|c|c|}
\hline \multicolumn{10}{|c|}{ Experiment 1} \\
\hline & $X_{1}$ & $\mathbf{X}_{2}$ & $\mathbf{Y}$ & $\mathbf{Y X}_{1}$ & $\mathbf{Y X}_{2}$ & $X_{1}^{2}$ & $\mathbf{X}_{2}^{2}$ & $\mathbf{Y}^{2}$ & $\mathbf{X}_{1} \mathbf{X}_{2}$ \\
\hline $\mathrm{O}$ & 3 & 4 & & & & & & & \\
\hline Al & 3 & 4 & 13500 & 40500 & 54000 & 9 & 16 & $1,82 \mathrm{E}+08$ & 12 \\
\hline$A^{r}$ & 4 & 3 & 13500 & 54000 & 40500 & 16 & 9 & $1,82 \mathrm{E}+08$ & 12 \\
\hline$A^{r}$ & 2 & 3 & 12900 & 25800 & 38700 & 4 & 9 & $1,66 \mathrm{E}+08$ & 6 \\
\hline$A \varepsilon$ & 2 & 3 & 12850 & 25700 & 38550 & 4 & 9 & $1,65 \mathrm{E}+08$ & 6 \\
\hline $\mathrm{A}^{0}$ & 2 & 4 & 12900 & 25800 & 51600 & 4 & 16 & $1,66 \mathrm{E}+08$ & 8 \\
\hline Sum & 13 & 17 & 65650 & 171800 & 223350 & 37 & 59 & $8,62 \mathrm{E}+08$ & 44 \\
\hline Average & 2,6 & 3,4 & 13130 & 34360 & 44670 & 7,4 & 11,8 & $1,72 \mathrm{E}+08$ & 8,8 \\
\hline \multicolumn{10}{|c|}{ Valuation object, UAH } \\
\hline & & & & 133 & & & & & \\
\hline
\end{tabular}

\begin{tabular}{|c|c|c|c|c|c|c|c|c|c|}
\hline \multicolumn{10}{|c|}{ Experiment 2} \\
\hline & $\mathbf{X}_{1}$ & $\mathbf{X}_{2}$ & $\mathbf{Y}$ & $\mathbf{Y X}_{1}$ & $\mathbf{Y X}_{2}$ & $\mathbf{X}_{1}^{2}$ & $\mathbf{X}_{2}^{2}$ & $\mathbf{Y}^{2}$ & $\mathbf{X}_{1} \mathbf{X}_{2}$ \\
\hline $\mathrm{O}$ & 3 & 3 & & & & & & & \\
\hline $\mathrm{A} 1$ & 3 & 3 & 13500 & 40500 & 40500 & 9 & 9 & $1,82 \mathrm{E}+08$ & 9 \\
\hline A2 & 5 & 2 & 13500 & 67500 & 27000 & 25 & 4 & $1,82 \mathrm{E}+08$ & 10 \\
\hline $\mathrm{A} 3$ & 1 & 2 & 12900 & 12900 & 25800 & 1 & 4 & $1,66 \mathrm{E}+08$ & 2 \\
\hline A4 & 1 & 2 & 12850 & 12850 & 25700 & 1 & 4 & $1,65 \mathrm{E}+08$ & 2 \\
\hline A5 & 1 & 3 & 12900 & 12900 & 38700 & 1 & 9 & $1,66 \mathrm{E}+08$ & 3 \\
\hline Sum & 11 & 12 & 65650 & 146650 & 157700 & 37 & 30 & $8,62 \mathrm{E}+08$ & 26 \\
\hline Average & 2,2 & 2,4 & 13130 & 29330 & 31540 & 7,4 & 6 & $1,72 \mathrm{E}+08$ & 5,2 \\
\hline \multicolumn{10}{|c|}{ Valuation object, UAH } \\
\hline \multicolumn{10}{|c|}{13378,95} \\
\hline
\end{tabular}

\begin{tabular}{|c|c|c|c|c|c|c|c|c|c|}
\hline \multicolumn{10}{|c|}{ Experiment 3} \\
\hline & $\mathbf{X}_{1}$ & $\mathbf{X}_{2}$ & $\mathbf{Y}$ & $\mathbf{Y X} \mathbf{X}_{1}$ & $\mathbf{Y X}$ & $\mathbf{X}_{1}^{2}$ & $\mathbf{X}_{2}^{2}$ & $\mathbf{Y}^{2}$ & $\mathbf{X}_{1} \mathbf{X}_{2}$ \\
\hline $\mathrm{O}$ & 4 & 3 & & & & & & & \\
\hline A1 & 4 & 3 & 13500 & 54000 & 40500 & 16 & 9 & $1,82 \mathrm{E}+08$ & 12 \\
\hline A2 & 5 & 2 & 13500 & 67500 & 27000 & 25 & 4 & $1,82 \mathrm{E}+08$ & 10 \\
\hline A3 & 3 & 2 & 12900 & 38700 & 25800 & 9 & 4 & $1,66 \mathrm{E}+08$ & 6 \\
\hline A4 & 3 & 2 & 12850 & 38550 & 25700 & 9 & 4 & $1,65 \mathrm{E}+08$ & 6 \\
\hline A5 & 3 & 3 & 12900 & 38700 & 38700 & 9 & 9 & $1,66 \mathrm{E}+08$ & 9 \\
\hline Sum & 18 & 12 & 65650 & 237450 & 157700 & 68 & 30 & $8,62 \mathrm{E}+08$ & 43 \\
\hline Average & 3,6 & 2,4 & 13130 & 47490 & 31540 & 13,6 & 6 & $1,72 \mathrm{E}+08$ & 8,6 \\
\hline \multicolumn{10}{|c|}{ Valuation object, UAH } \\
\hline & & & & & & & & & \\
\hline
\end{tabular}




\section{Discussion of the research results on methods for implementing a comparative approach in real estate valuation}

To date, the main methods that implement a comparative approach in the valuation of property and real estate is the method of expert evaluation, the method of calculating corrective corrections based on the solution of a system of linear equations, the method of calculating corrective corrections based on the normalized distances in the space of pricing factors, and the correlation-regression method.

Comparison of the results of calculations of the value of the object valuation by various methods has shown that the expert method, as the most subjective, gives the most overestimated value of real estate objects; the method of SLAE solution and the method of determining the weight coefficients on the basis of the normalized distances in the space of the pricing factors show a somewhat understated valuation (Fig. 1).

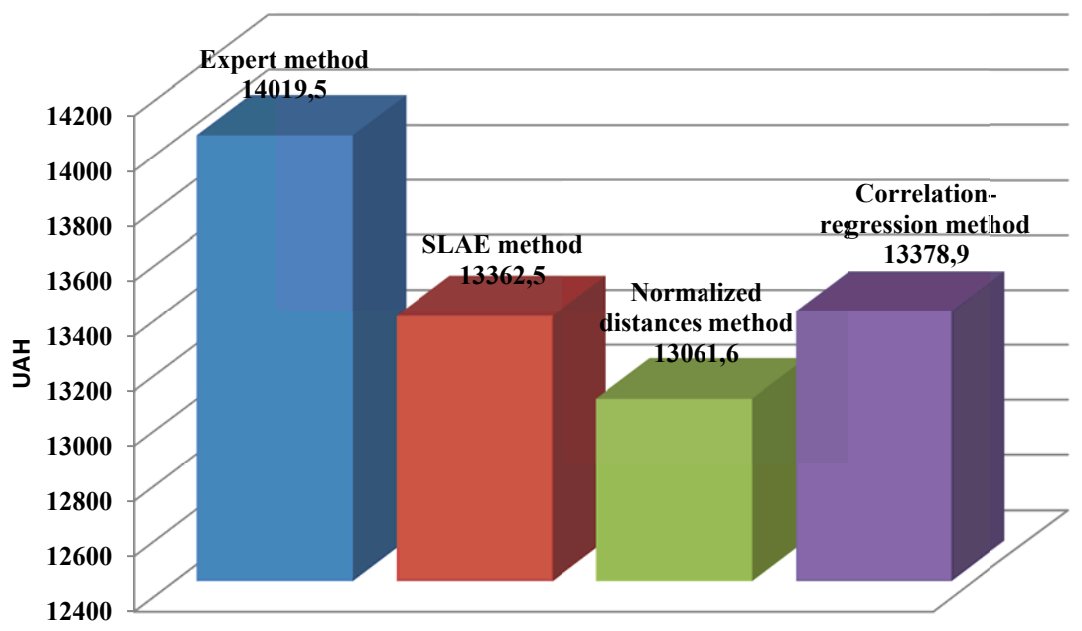

Fig. 1. The results of calculating the value of the property by different methods

In addition, the analysis of the results of a computational experiment on the influence of methods of digitizing the initial data on the final value of the real estate object when implementing various methods has shown that the method of calculating corrective corrections based on the solution of a system of linear equations and the method of calculating weight coefficients on the basis of the normalized distances in the space of pricing factors essentially depend on the method of digitizing the initial data, while the correlation-regression method does not exert addiction is without suspended its advantage.

\section{Conclusions}

Valuation of property and property rights is an important prerequisite for the functioning and development of civilized market relations. Therefore, the problems associated with the improvement of valuation and appraisal activity are always topical.

Modern practice of valuation of real estate has a significant methodological and calculating apparatus for making sound management decisions. However, the proposed economic and mathematical models in most are aimed at reflecting the general trends in the development of the real estate market, while the real estate market is characterized by variability and multifactoriness, which makes it necessary to take into account its stochastic nature in computational models.

On the basis of the research carried out in the work, it can be concluded that today the most expedient in valuation of real estate is the development and improvement of methods of correlation and regression analysis, it allows not only to determine the current market value of real estate objects, but also to establish investigative causality. Obligations between pricing factors, predicting qualitative and quantitative changes in the real estate market, is an integral part in making the most effective management solutions.

The methods and results of scientific research presented in this work are used in the evaluation of real residential and non-residential real estate LLC “Tasador” (Kyiv, Ukraine). 


\section{References}

[1] Markus, Y. I. (2010). Praktika otsenki imushchestva. Kriticheskiy analiz normativnoy bazy otsenok imushchestva. Ukrainskaya investitsionnaya gazeta, 3, 274.

[2] Kucherenko, V. R., Kvach, Ya. P., Smentina, N. V. et al. (2009). Otsinka biznesu ta nerukhomosti. Kyiv: Tsentr uchbovoi literatury, 200.

[3] Voronina, L. I., Vorotin, V. E., Lisnik, V. G., Polishchuk, V. M. (2005). Otsinka mayna v Ukraini. Vol. 1. Nerukhome mayno. Kyiv: Vidavnitstvo Evropeys'kogo universitetu, 217.

[4] Kucherenko, V. R., Zaets, M. A., Zakharchenko, O. V., Smentina, N. V., Ulibina, V. O. (2013). Otsinka ta upravlinnya nerukhomistyu. Odesa: Vidavnitstvo TOV «Leradruk», 272.

[5] Zrobek, S. (Ed.) (2011). Selected aspects of the cost approach in property valuation. Olsztyn: Polish Real Estate Scientific Society, 104. Available at: http://tnn.org.pl/tnn/publik/19/Monografia_XIX_2011.pdf

[6] William, J., Lawson, W. (2008). Theory of real estate valuation. School of Economics, Finance and Marketing, 115. Available at: https://researchbank.rmit.edu.au/eserv/rmit:6724/Lawson.pdf

[7] Voronin, V. O., Lyantse, E. V., Mamchyn, M. M. (2014). Analityka rynku nerukhomosti: metodolohiya ta pryntsypy suchasnoyi otsinky. Lviv: Mahnoliya, 304.

[8] Gribovskiy, S. V., Sivets, S. A. (2008). Matematicheskiye metody otsenki nedvizhimogo imushchestva. Moscow: Finansy i statistika, 368.

[9] Linne, M. R. Real Estate Statistics Without Fear. Statistical Analysis In Real Estate Appraisal. Center of Valuation Economics, 98. Available at: http://appraisalworld.com/compcruncher_website/resources/ Statistics\%20Without\%20Fear\%20Workbook.pdf

[10] Kokot, S., Bas, M. (2013). Evaluation of the Applicability of Statistical Methods in Studies on Price Dynamics on the Real Estate Market. Real Estate Management and Valuation, 21 (1), 49-58. doi: 10.2478/remav-2013-0007

[11] Benjamin, J. D., Guttery, R. S., Sirmans, C. F. (2004). Mass Appraisal: An Introduction to Multiple Regression Analysis for Real Estate Valuation. Journal of Real Estate Practice and Education, 7 (1), 65-77.

[12] Bitner, A. (2007). Konstrukcja modelu regresji wielorakiej przy wycenie nieruchomosci. Acta Scientiarum Polonorum, Administratio Locorum, 6 (4), 59-66.

[13] Baranska, A. (2010). Statystyczne metody analizy i weryfikacji proponowanych algorytmow wyceny nieruchomosci. Krakow: Akademii Gorniczo-Hutniczej im. Stanislawa Staszica, 122.

[14] Lovaglio, P. G., Vittadini, G. (2012). Multilevel dimensionality-reduction methods. Statistical Methods \& Applications, 22 (2), 183-207. doi: 10.1007/s10260-012-0215-2

[15] Hardouin, C., Cressie, N. (2017). Two-scale spatial models for binary data. Statistical Methods \& Applications, 1-24. doi: 10.1007/s10260-017-0391-1

[16] Mach, L. (2017). The Application of Classical and Neural Regression Models for the Valuation of Residential Real Estate. Folia Oeconomica Stetinensia, 17 (1), 44-56. doi: 10.1515/foli-2017-0004

[17] Sarip, A. G., Hafez, M. B., Daud, M. N. (2016). Application of fuzzy regression model for real estate price prediction. Malaysian Journal of Computer Science, 29 (1), 15-27.

[18] Ma, H., Chen, M., Zhang, J. (2015). The Prediction of Real estate Price Index based on Improved Neural Network Algorithm. Advanced Science and Technology Letters, 81, 10-15. doi: 10.14257/ astl.2015.81.03 